\title{
Hot Pepper viii. Reduction of Microbial Spoilage and Physio-chemical Deterioration in Processed Caribbean Peppers
}

\author{
Puran Bridgemohan ${ }^{1}$, Majeed Mohammed ${ }^{2}$, Ronell S. H. Bridgemohan ${ }^{3} \&$ Zareef Mohammed $^{4}$ \\ ${ }^{1}$ Biosciences Agriculture and Food Technology, The University of Trinidad and Tobago Waterloo Research \\ Campus, Carapichaima, Trinidad \\ ${ }^{2}$ Department of Food Production, Faculty of Food and Agriculture, University of the West Indies, Trinidad \\ ${ }^{3}$ Georgia College and State University, GA, USA \\ ${ }^{4}$ University of Miami, USA \\ Correspondence: Majeed Mohammed, Department of Food Production, Faculty of Food and Agriculture, \\ University of the West Indies, Trinidad. E-mail: majeed.mohammed@ sta.uwi.edu
}

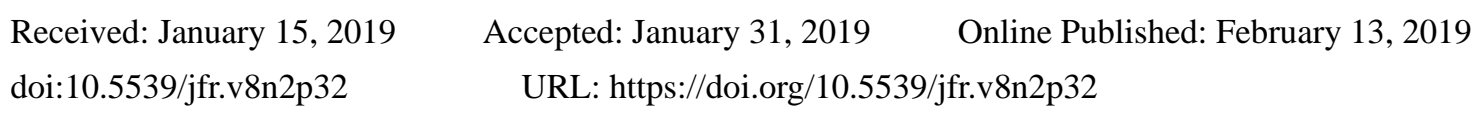

\begin{abstract}
The quality in the small producers' hot pepper industry is affected by microbial and thermal processing which reduces the physio-chemical qualities of the final product particularly colour retention and to a lesser extent pungency. A series of studies explored the causes and evaluated some protocols to reduce microbial infection and the loss of pigment using varying sealant caps of vegetable oil and sodium chloride, in addition to preserving agents (calcium chloride, ascorbic acid, sodium benzoate, sodium chloride, and calcium citrate). The result confirmed that red pepper mash in $100 \mathrm{~g} \mathrm{CaCl}_{2}$ (calcium chloride) submerged under vegetable oil sealant cap retained "L", 'a', 'b' colour coordinates as the fresh peppers beyond 100 days with no loss of colour, pungency and flavour.
\end{abstract}

Keywords: microbial infection, physio-chemical, capsanthin, hot peppers

\section{Introduction}

The Caribbean has become renowned for its colourful and flavourful hot peppers (Scotch bonnet) and the infamous Trinidad Scorpion and Carvalho hot which are ranked amongst the world's hottest peppers (Capsicum chinensis L.). There is more than one dozen such highly pungent peppers grown in the Caribbean for either fresh consumption or processing. It is very competitive and risky for small producers to trade in the fresh hot pepper markets in the USA and Europe. As a consequence, it is necessary to seek alternative approaches to combat the two major challenges that the industry is plagued with viz: microbial spoilage and colour degradation. Further, the quality of processed hot pepper products such as flakes, mash and sauces are also affected by physio-chemical deterioration. The quality of these value-added products particularly colour, consumer acceptance, and to a lesser extent pungency are reduced. Bridgemohan et al. (2018a, b) improved colour retention in flakes and mash in several Caribbean pepper varieties, but these are still at an unacceptable level.

With respect to colour, the pigment content (chlorophylls, anthocyanin and carotenoids viz; capsanthin, capsorubin zeaxanthin, lutein, and cryptocapsin, and $\alpha$ and $\beta$ carotene) increased as the fruit ripened until post maturity (Mohamed \& Bridgemohan, $2014 \mathrm{a} \& \mathrm{~b}$ ). The mature fresh fruits under ambient conditions had a shelf life of 4 - 5 days with minimal loss of quality, which could eventually be extended up to 14-15 days at non-chilling temperature regimes (Bridgemohan et al. 2017a; Mohammed et al., 2014). Similarly, immediately after harvest, storage and transportation losses due to physiological, biochemical and microbiological activities could be reduced significantly (Mohammed et al., 2016).

Several flavour compounds were identified in fresh pepper and pepper mash viz: 2-pentanone, 3-hexanol, acetic acid, oleic acid, and linoleic acid. However, the compounds (E)-2-undecenal, farnesol, 2-pentadecyn-1-ol, linolenic acid, and squalene are found only in the fresh pepper and not processed products. This suggested that the observed browning reactions in the mash could be an interaction of physio-chemical and microbial degradation, but it is yet to be confirmed (Gogus et al., 2015). 
Spoilage in pepper mash may be induced by exposure to heat and faeco-oral route infections, or changes to metabolic processes resulting in undesirable or unacceptable sensory characteristics (Koh 2005). If pathogens or toxins are involved, there are undesirable changes in texture, aroma, taste, or appearance. More often, spoilage is induced by exposure to air, microorganisms (bacteria, yeasts and molds), or improper storage conditions (Bridgemohan et al., 2018a; 2017a, b).

Microbial spoilage in hot pepper products can be visible as mold growth embedded in a mass of filaments with brown colour changes due to the bacterial acidification caused by L. mesenteroides (Koh, 2000), Listeria spp. ( $L$. gelidumsubsp. gasicomitatum, L. piscium (Pothakos, Vasileios et al., 2014), Klebsiella pneumoniae, Pseudomonas aeruginosa, Enterococcus faecalis, Micrococcus luteus, or Escherichia coli (Natheer, 2010), and Clostridium perfringens and Staphylococcus aureus (Draughton et al, 1981). Flagan \& Leadbetter (2006) showed that the reduction in flavour and pungency maybe caused by the growth and utilization of capsaicin nutrient by certain bacteria (Pseudomonas and Variovorax spp).

The physio-chemical changes are observed in the top layers as brown pigments. This maybe both $\mathrm{pH}$ and temperature dependent. Increasing $\mathrm{pH}$ ( 3 to 4$)$ can affect the rate of non-enzymatic browning reactions as a function of temperature (Gogus \& Sami, 1998). Flores et al. (2007) noted that while fermentation of chili peppers is dependent on several factors including microbial flora, non-desirable microbial growth could be controlled using $\mathrm{CaCl}_{2}$ treatments. Lee, Jang \& Hwang (2002) found that plastic films with appropriate gas permeability, such as co-extruded multilayer polyamide, may be the most practical choice based on consideration of both volume expansion and quality retention of the fermented paste.

Vega-Gálvez (2009) observed that dry conditions, particularly temperature, leads to pepper modifications that can cause quality degradation. The radical scavenging activity showed higher antioxidant activity at higher temperatures $\left(80\right.$ and $\left.90^{\circ} \mathrm{C}\right)$ rather than at lower temperatures $\left(50,60\right.$ and $\left.70{ }^{\circ} \mathrm{C}\right)$.

Steaming and gamma irradiation are found to enhance the physio-chemical and microbiological properties of dried red pepper during post-treatment storage at a refrigerated temperature $\left(4 \pm 2{ }^{\circ} \mathrm{C}\right.$ ) (Rico et al., 2010). The application of chlorine dioxide $\left(\mathrm{ClO}_{2}\right)$ gas treatment can be a potential effective method of pathogen reduction for Escherichia coli O157:H7 (Han et al., 2000).

This study is part of a series of experiments which evaluated two approaches to reduce the microbial contamination and pigment deterioration in processed Caribbean peppers. The major issues in processing of red and yellow hot peppers are loss of colour and pungency, and microbial spoilage. The University of Trinidad and Tobago (UTT) in partnership with the major pepper producers and the Export Marketing Agency, undertook the responsibility to assess colour stability and retention of pungency in processed products of selected Caribbean hot peppers destined for the export trade. Consequently, the objective of this study is to determine the effects of preserving agents on the physio-chemical changes on colour stability and shelf-life as well as the reduction of microbial contamination in hot peppers produced in the Caribbean.

\section{Materials and Methods}

This study was conducted during the period 2014-2018. Experiments were conducted at the laboratories of the St. Augustine Campus, University of the West Indies and at the Biosciences, Agriculture and Food Technology, University of Trinidad and Tobago. All the peppers used in the study were cultivated at the Waterloo Research Campus Field Station, and only if necessary, procured from reputable farmers for consistent quality and colour. The crop agronomy and postharvest treatments, as well as the methodology used in the mash preparation and sealant caps were previously described and reported by Bridgemohan and Mohammed (2018). The varieties used based on colour were Trinidad scorpion (Red) and Scotch bonnet (yellow). Three separate studies were conducted which addressed the following parameters of colour stability, microbial infection and discoloration, and enhanced mash quality.

\section{Study 1. Effects of preserving agents [Pa] and capping [Sc] on colour retention}

The pepper mash was processed using freshly harvested and sanitized (250 ppm sodium hypochlorite] cv. Carvalho hot peppers. Two (2) $\mathrm{kg}$ samples of the puree or mash were topped with one litre of the preserving agents [Pa]; acetic, citric acid, and ethanol. To the acetic and citric acids $5 \mathrm{~g}$ sodium benzoate were added, while no preservatives were applied to the control. The sealant or caps [Sc] were developed using wax paper layer which were placed on top of the mash to eliminate cross-contamination. The Sc evaluated were $500 \mathrm{ml}$ of vegetable oil and $100 \mathrm{~g} \mathrm{NaCl}$, and a control [zero cap]. This experiment covered a period of more than 500 days. All samples were keep in the dark.

Changes to fruit colour were monitored monthly using a portable tristimulus Minolta Chromameter (Model 
CR-200, Minolta Corp, Ramesy, NJ). The meter was calibrated with a white standard plate (Minolta calibration plate CR-A43) and fruit chromaticity was measured in "L", 'a', 'b' coordinates.

\section{Study 2. Effect of Sealant Cap (Sc) and Preserving Agent (Pa) on microbial infection (MI) and discoloration $(\%)$}

The methodology used in the mash preparation and sealant caps were similar to the above study, and the varieties used based on colour were Trinidad scorpion (red) and Scotch bonnet (yellow). The Sealant Caps (Sc) were oil, salt, no cap, and the Preserving Agents (Pa), included citric acid, alcohol, acetic acid, sodium benzoate, and control (Table 1). The jar size used was $500 \mathrm{ml}$, and each treatment was replicated 10 times. Changes in colour and spoilage were monitored over a 2-year period.

Table 1. Preserving agent [Pa] treatments used in the study.

\begin{tabular}{ll}
\hline Preserving agent [Pa] & Code \\
\hline Sodium Chloride & $\mathrm{NaCl}$ \\
Sodium Benzoate & $\mathrm{NAB}$ \\
Calcium Chloride & $\mathrm{CaCl}_{2}$ \\
Ascorbic Acid & $\mathrm{ASC}$ \\
Calcium citrate & $\mathrm{CALCTIR}$ \\
Citric acid & $\mathrm{CA}$ \\
Acetic Acid & $\mathrm{ACA}$ \\
\hline
\end{tabular}

\section{Study 3. Effect Preserving Agent (Pa) on physio-chemical and microbial infection (MI) on pepper mash} quality

This study advanced the results of Study 2, and only the vegetable oil sealant cap [Sc] was further evaluated using both red and yellow hot peppers, and 5 Preserving Agents [Pa]. The Pa included calcium chloride, ascorbic acid, sodium benzoate, sodium chloride, and calcium citrate. There were two controls that had no Pa, but one was not sanitized. This allowed for the observation of the movement of field microbes into the pack house operations. In addition to changes in colour pigments, the $\mathrm{pH}$ and total soluble sugars [TSS] were measured, and the level of microbial infection was monitored on fortnightly basis for a period of 100 days. The experiment was a completely randomized block design with 2 colours $[\mathrm{Co}]$ and 5 persevering agents $[\mathrm{Pa}]$ with five replicates.

All data were subjected to generalized linear modelling (GLIM) using Minitab Statistical Software, and where necessary, variables were first subjected to log transformation and were then analyzed. For all comparisons, significance was defined at $\mathrm{p} \leq 0.05$.

\section{Results and Discussion}

\section{Study 1. Effect of Preserving Agent (Pa) and Sealant Cap (Sc) on colour (Co) stability}

All the preserving agents $(\mathrm{Pa})$, regardless of the sealant cap $(\mathrm{Sc})$ did not improve the quality of the mash which resulted in a significant loss in colour or pigment degradation. In the red peppers, there was a marked reduction in L (21\%), a* (79\%), and b (67\%), compared to the yellow for L (45\%), $\mathrm{a}^{*}(72 \%)$ and b (82\%)] after 100 days (Table 2). The regression analysis of the main factors ( $\mathrm{Sc}, \mathrm{Pa}$ and $\mathrm{Co}$ ) and its various interactions on $\mathrm{L}$, revealed that only Sc was significant ( $\mathrm{P} \geq 0.05)$, [Equation 1]. Further, the oil cap sealant performed better than both salt $(\mathrm{NaCl})$ and no cap for both yellow and red peppers (Table 2).

$$
\mathrm{Y}_{\mathrm{L}^{*}}=37.7-2.39 \mathrm{Sc}+0.01 \mathrm{Co}-0.85 \mathrm{~Pa}+0.24 \mathrm{Sc} * \mathrm{Co} * \mathrm{~Pa}+0.17 \mathrm{~S}^{*} \mathrm{Co}: \mathrm{R}^{2}=85.87 \% \text {. }
$$

Of the colour variables ( $\mathrm{L}, \mathrm{a}^{*} \mathrm{~b}^{*}$ and Hue angle), only, $\mathrm{L}$ and $\mathrm{a}^{*}$ appeared to be affected by the preserving agents and sealant caps. The $\mathrm{a}^{*}$ for red coloured peppers appeared to have been influenced more significantly $(\mathrm{P} \geq 0.005)$ compared to yellow with interactions of sealants, preserving agents and colour (Equation 2).

$$
\mathrm{Y}_{\mathrm{a}}^{*}=14.5+0.40 \mathrm{Sc}-4.96 \mathrm{Co}-0.05 \mathrm{~Pa}+0.28 \mathrm{Sc} * \mathrm{Co} * \mathrm{~Pa}-0.47 \mathrm{Sc} * \mathrm{Co} * \mathrm{~Pa}: \mathrm{R} 2=80.0 \% \text {. }
$$

The higher retention of red colouration over yellow was very noticeable as evidenced in the ANOVA presented hereunder: 


\begin{tabular}{lllcl}
\hline Predictor & Coef & SE Coef & \multicolumn{1}{c}{ T } & \multicolumn{1}{c}{ P } \\
\hline Constant & 14.50 & 3.58 & 4.04 & 0.000 \\
$\mathrm{Sc}$ & 0.40 & 1.24 & 0.32 & 0.751 \\
$\mathrm{Co}$ & -4.95 & 1.58 & -3.13 & $0.005^{* * *}$ \\
$\mathrm{~Pa}$ & -0.05 & 0.81 & -0.07 & 0.946 \\
$\mathrm{Sc} * \mathrm{Co} * \mathrm{~Pa}$ & 0.28 & 0.21 & 1.27 & 0.218 \\
\hline
\end{tabular}

Generally, acetic acid [ACA] seemed to be the more effective Pa in the maintenance of colour stability compared to the others for both pepper colour in the oil sealant cap (Table 2).

\section{Study 2. Effect of Sealant Cap (Sc) and Preserving Agent (Pa) on microbial infection (MI) and discoloration (\%)}

The effect of the Sc and Pa and its various interactions on MI were subjected to the GLIM analysis, and the best fit (Equation 3) indicated that only the main factor Sealant Cap [Sc] had any significant $(\mathrm{P} \geq 0.005)$ effect.

$$
\mathrm{Y}_{\mathrm{MI}}=22.2+0.1 \mathrm{Co}+1.62 \mathrm{~Pa}+0.13 \mathrm{Sc}: \mathrm{R}^{2}=53 \%
$$

\begin{tabular}{lllllcl}
\hline Source & DF & Seq SS & Adj SS & Adj MS & F & P \\
\hline Sc & 3 & 9163.5 & 9871.9 & 3290.6 & 5.63 & $0.005^{* * *}$ \\
$\mathrm{~Pa}$ & 4 & 4630.6 & 4668.5 & 1167.1 & 2.00 & 0.132 \\
$\mathrm{Co}$ & 1 & 50.2 & 50.2 & 50.2 & 0.09 & 0.772 \\
\hline
\end{tabular}

Generally, the mean microbial infection (3.3\%) was significantly lower than the salt treatment $(36.9 \%)$ and no cap $(42.5 \%)$. Also, in red peppers there was no effect of $\mathrm{Pa}$ or Co on microbial infection. The colour of the fresh pepper appeared to be easily subjected to discoloration, regardless of the preserving agent (Eqn 3). The GLIM ANOVA revealed the discoloration was affected by $\mathrm{Co}$ and $\mathrm{Sc}$ interactions as presented hereunder:

\begin{tabular}{lll}
\hline Source & DF & Seq SS \\
\hline $\mathrm{SC}$ & 3 & 9163.48 \\
$\mathrm{~Pa}$ & 4 & 4630.62 \\
$\mathrm{Co}$ & 1 & 50.21 \\
$\mathrm{Sc}^{*} \mathrm{~Pa}{ }^{*} \mathrm{Co}$ & 15 & 3707.71 \\
$\mathrm{Sc} \mathrm{Pa}^{*}$ & 11 & 7968.35 \\
$\mathrm{~Pa}^{*} \mathrm{Co}$ & 7 & 115.50 \\
$\mathrm{Sc} \mathrm{CO}^{*} \mathrm{O}$ & 5 & 0.00 \\
\hline
\end{tabular}

The mean discoloration of oil caps sealant (25.9\%) was significantly lower than both salt and no cap (42.5\%) treatments. Further analysis indicated that there was no correlation between microbial infection and discoloration. Generally, the red pepper treatments with no Pa under oil Cap had zero spoilage. With the exception of alcohol preserving agent, all the $\mathrm{Pa}$ in oil Cap prevented microbial infection for both colours unlike the other treatments.

\section{Model Reduced}

\begin{tabular}{lllll}
\hline Predictor & Coef & SE Coef & \multicolumn{1}{c}{$\mathrm{T}$} & \multicolumn{1}{c}{$\mathrm{P}$} \\
\hline Constant & 20.29 & 1.40 & 14.44 & 0.000 \\
$\mathrm{Co}^{2}$ & -3.70 & 0.37 & -9.83 & $0.000^{* *}$ \\
$\mathrm{~Pa}^{2}$ & 0.11 & 0.07 & 1.55 & 0.130 \\
$\mathrm{~Pa}$ & 1.22 & 0.70 & -1.73 & $0.091^{*}$ \\
$\mathrm{Co}{ }^{*} \mathrm{~Pa}$ & 0.25 & 0.25 & & 0.323 \\
\hline
\end{tabular}

The effect of the Pa in oil Sc treatments after 100 days revealed significant variations between $\mathrm{L}(1.642 \pm 0.504)$ for all $\mathrm{Pa}$ treatments (Table 3), and $\mathrm{L}$ value for yellow peppers were higher than red and increased with $\mathrm{Pa}$ resulting in significant interactions [Equation 4]. The converse was observed for $\mathrm{a}^{*}$, with an interaction between colour and preserving agents [Equation 5], where the $\mathrm{a}^{*}$ for red pepper was significantly higher than all $\mathrm{Pa}$ $(14.96 \pm 0.727)$ compared to that of the yellow pepper $(4.85+0.825)$. The $b^{*}$ displayed a significant quadratic response for both $\mathrm{Co}$ and $\mathrm{Pa}$ with no interaction [Equation 6] and its $\mathrm{b}^{*}$ also varied significantly between $\mathrm{Pa}$ $(11.2 \pm 0.742)$. 
Table 2. The effect of the Preserving Agents in Oil cap treatments after 100 days

\begin{tabular}{llll}
\hline $\mathrm{Y}$ & \multicolumn{1}{c}{ Response } & $\mathbf{R}^{2}$ & Equation \\
\hline $\mathrm{Y}_{\mathrm{L}^{*}}$ & $39.2+2.65 \mathrm{Co}^{2}+0.47 \mathrm{~Pa}^{2}-1.84 \mathrm{~Pa}-1.04 \mathrm{Co}^{*}$ & 73.1 & 4 \\
$\mathrm{Y}_{\mathrm{a}^{*}}$ & $20.3-3.71 \mathrm{Co}^{2}+0.113 \mathrm{~Pa}^{2}-1.23 \mathrm{~Pa}+0.25 \mathrm{Co} \mathrm{Pa}^{*}$ & 90.7 & 5 \\
$\mathrm{Y}_{\mathrm{b}^{*}}$ & $1.76 \mathrm{Co}^{2}+0.582 \mathrm{~Pa}^{2}-4.64 \mathrm{~Pa}+13.8$ & 48 & 6 \\
\hline
\end{tabular}

Study 3. Effect Preserving Agent (Pa) on physio-chemical and microbial infection (MI) conditions on pepper mash quality

Table 3. Colorimetric Readings on Red and Yellow Pepper Mash

\begin{tabular}{lllll}
\hline Colour & Treatment & $\mathbf{L}^{*}$ & $\mathbf{a}^{*}$ & $\mathbf{b}^{*}$ \\
\hline Red & ASC & 39.71 & 12.91 & 4.35 \\
& CACl $_{2}$ & 37.39 & 16.87 & 11.86 \\
& CALCTIR & 44.44 & 17.04 & 13.51 \\
& Control & 36.64 & 15.59 & 10.02 \\
& NAB & 38.02 & 11.16 & 3.58 \\
& NACL & 42.11 & 15.45 & 9.14 \\
& Unsanitized & 39.94 & 15.69 & 8.09 \\
Yellow & ASC & 43.23 & 4.66 & 12.38 \\
& CACl & 42.76 & 5.50 & 15.29 \\
& CALCTIR & 46.81 & 4.53 & 18.16 \\
& Control & 45.12 & 4.35 & 16.35 \\
& NAB & 38.92 & 5.13 & 6.04 \\
& NACL & 42.67 & 6.01 & 13.94 \\
& Unsanitized & 45.24 & 3.80 & 15.25 \\
& X & 43.53 & 9.9 & 16.7 \\
& se & 3.077 & 5.41 & 4.34 \\
\hline
\end{tabular}

There were no significant changes in $\mathrm{L}$ for red mashes regardless of the Pa, but in the yellow mashes there was a 25 to $40 \%$ decrease in $\mathrm{L}$ values for all the Pa treatments (Table 3). The $\mathrm{a}^{*}$ and $\mathrm{b}^{*}$ for both red and yellow mashes deteriorated by $>50 \%$, and there was no treatment effect. The microbial infection was affected by both pepper colour and the preserving agent [Equation 7].

$$
\mathrm{MI} \%=-23.0+6.3 \mathrm{Co}+3.57 \mathrm{~Pa}-0.11 \mathrm{Co} * \mathrm{~Pa} . \mathrm{R}^{2}=85.42 \%
$$

The infection was due to either bacteria or fungi, but no evidence of cross infections or contaminations were visible. It was observed that the microbial [Bacteria] infection (42\%) for red mash was lower than yellow mash (61.5\%). The MI due to fungi (10\%) was less and the same for both colour mashes (Table 4). The ASC, CACL, CALCITR and NACL exhibited higher bacterial infection (44 to 100\%) compared to the sanitized control (29\%) in the Yellow mashes. All of the Pa's with the exception of CALCITR reduced the MI spoilage between 0 to $15 \%$. The $\mathrm{CACl}_{2}$ provided good protection against both bacterial and fungal infection in red peppers. The major bacterial were the gram negative rods (Table 5). 
Table 5. The Effects Preserving Agent (Pa) on microbial infection (MI) and physio-chemical conditions on pepper mash quality

\begin{tabular}{|c|c|c|c|c|c|c|}
\hline \multirow{2}{*}{$\begin{array}{l}\text { Colour } \\
{[\mathrm{Co}]}\end{array}$} & \multirow{2}{*}{$\begin{array}{l}\text { Preserving Agent } \\
{[\mathrm{Pa}]}\end{array}$} & \multicolumn{3}{|l|}{ Microbial } & \multicolumn{2}{|c|}{ Physio-chemical } \\
\hline & & $\begin{array}{l}\text { \% Spoilage } \\
{[\mathrm{MI}]}\end{array}$ & Gram Stains & $\begin{array}{l}\text { Motility Agar } \\
\text { Test }\end{array}$ & $\mathrm{pH}$ & ${ }^{\circ}$ Brix \\
\hline \multirow{3}{*}{ Yellow } & ASC & 100 &,+ rods & - & 4 & 8.8 \\
\hline & NAB & 36.3 &,- rods & + & 4 & 8.3 \\
\hline & $\mathrm{CACl}_{2}$ & 44 & -, rods & - & 5 & 18.3 \\
\hline \multirow{9}{*}{ Red } & NACL & 100 &,- rods & - & 4 & 4.9 \\
\hline & Control & 29 & -, rods & + & 5.4 & 6.24 \\
\hline & CALCTIR & 85 & -, rods & - & 4 & 4.6 \\
\hline & ASC & 2 & -, rods & + & 4 & 8.8 \\
\hline & NAB & 15 & -, rods & - & 4 & 8.3 \\
\hline & $\mathrm{CACl}_{2}$ & 0 & 0 & 0 & 4 & 18.3 \\
\hline & NACL & 2 & - , rods & - & 5 & 18.3 \\
\hline & Control & 25 & - , rods & + & 4 & 6.4 \\
\hline & CALCTIR & 29 & -, rods & + & 4 & 7.8 \\
\hline
\end{tabular}

Generally, the yellow pepper mash was more susceptible to physio-chemical changes (72.5\%) compared to red (25\%). The two variables monitored were $\mathrm{pH}$ and ${ }^{\circ} \mathrm{Bx}$, and it was observed that the $\mathrm{Pa}$ had no effect on the $\mathrm{pH}$ and varied between 4 to 5.4 . The $\mathrm{CaCl}_{2}$ treatment increased the ${ }^{\circ} \mathrm{Bx}$ to 18.3 in both colours, and was similar $\mathrm{NaCl}$ for red only. The ${ }^{\circ} \mathrm{Bx}$ was generally low for all treatments (4.9 to 8.3) and was affected by Pa (Equation 8).

$$
\mathrm{Y}_{\mathrm{Bx}}^{\mathrm{o}}=-2.1+9.24 \mathrm{~Pa}: \mathrm{R}^{2}=72.43 \%
$$

There were no changes in the $\mathrm{pH}(4.3+-0.82)$ in all of the various mashes regardless of colour and preserving agents. The $\mathrm{CaCl}_{2}$ has proven to enhance the shelf-life of peppers by controlling the development of physiological disorders eg., reducing browning (Samira et al. 2013; Yildiz, 2018). It improved the stabilization on the membrane systems and the formation of calcium-pectate which increased the rigidity of cell walls and inhibited degradation (Mignani et al., 1995). This made the pepper cell walls less accessible to the enzymes that could promote softening and cellular leakages (Stanely et al., 1995). The $\mathrm{CaCl}_{2}$ reduced the formation of the brown pigments as the $\mathrm{pH}$ was not affected, thus suppressing the non-enzymatic colour changes as suggested by Gogus and Sami (1995).

The ${ }^{0}$ Brix contents of the of intensely green mature peppers varieties ranged from 3.5 to 6.43 (Mohammed et al., 1999; Antoniali et al., 2007). However, it was observed from this study that the $\mathrm{CaCl}_{2}$ treatment increased the ${ }^{\circ}$ Brix from 4.9 and 8.3 to 18.3. Getenit et al. (2008) confirmed that ${ }^{\circ}$ Brix contents of stored peppers can result in faster conversion of starch into water-soluble sugars which was facilitated with the $\mathrm{CaCl}_{2}$. According to Antoniali et al. (2007) the polysaccharides of the cell wall are broken up with consequent increases in sugar levels during ripening.

After 100 days the $\mathrm{pH}$ in the study varied between 4.0 to 5.4 , which are slightly more acidic than that reported by Medlicott et al.(1986). The reported $\mathrm{pH}$ values in the range of 5.99 showed an increasing trend during storage time. The observable changes in $\mathrm{pH}$ could be due to variations in citric, malic and ascorbic acid concentrations since these acids are known to diminish during ripening.

Antoniali et al. (2007) also reported that there were no significant differences in $\mathrm{pH}$ values of pepper during ripening. However Medlicott et al. (1986) had previosly confirmed there was a tendency of increasing pH values and reduced acidity with prolonged storage time, since the fruit preceeding the ripening process is going to diminish its predominant malic acid. According to Mizrach et al. (1997), carbohydrate and acid metabolism are closely connected during postharvest ripening period which would thus raise $\mathrm{pH}$ of the produce pungency.

The processed mashes retained a high level of pungency and appeared to be higher than results of Gibbs \& O'Garro (2004) for mature fruits. During ripening, capsaicin concentration reached a maximum then it turned over and degraded to secondary products (Bernal and Barcelo, 1996), thus confirming why the mash may not be as pungent as the fresh fruits. It is assumed that peroxidases catalyze capsasinoid oxidation and plays a central role in its metabolism in pepper (Yu et al., 2005). Peroxidase activity is lower in fruits which have low moisture content (Bernal and Barcelo 1996). Lower peroxidase and capsaicin oxidase activity means that the oxidation, or breakdown, of capsaicin will be slower when fruits have low moisture. 


\section{Conclusion}

The study indicated that red hot pepper mash had better post processing qualities with lower deterioration and physio-chemical changes. Further, the addition of $\mathrm{CaCl}_{2}$ as preserving agent in the red pepper mash, inhibited microbial infection and growth for both bacterial and fungal organisms. The Trinidad scorpion red pepper was able to maintain the aroma, consistency and pungency / taste as in the fresh state. The preserving agents maintained the ${ }^{\circ} \mathrm{Bx}$ at 18.3 which was similar to the fresh state, in addition to colour retention. It can be concluded that for export purposes, the red pepper preserved with $\mathrm{CaCl}_{2}$ under the oil cap sealant can be recommended to reduce spoilage and maintain integrity of post processed peppers.

\section{Acknowledgements}

The Authors are grateful for the field and laboratory support from the staff at UWI (Keshwar John) and UTT ( Selena Kahn, Karlene Fortune, Kimberly Singh, Abigail Le Gendre, Robbin Balroop, Puran Jaikaran, and H Bisson), for their hard work and effort in the maintenance of the crop and the analysis of the samples.

\section{References}

Antoniali, S. A., Paulo, M. L., Ana, M. M., Rogério, T. F., \& Juliana, S. (2007). Physico-chemical characterization of 'zarco hs' yellow bell pepper for different ripeness stages. Sci Agric., 64, 19-22. https://doi.org/10.1590/S0103-90162007000100003

Bernal, M. A., \& Barceló, A. R. (1996). 5,5'-dicapsaicin, 4'-O-5-dicapsaicin ether, and dehydrogenation polymers with high molecular weights are the main products of the oxidation of capsaicin by peroxidase from hot pepper. J Agric Food Chem., 43, 352-355. https://doi.org/10.1021/jf00050a017

Bridgemohan, P., Mohamed, M., \& Mohammed, M. (2016). Hot Peppers IV. Relative pungency of the Carvalho Hot Selection. International Journal of Research and Scientific Innovation (IJRSI), 3(8), 17-29.

Bridgemohan, P., Mohammed, M., \& Bridgemohan, R. S. H. (2017b). In Fruit and Vegetable Phytochemicals: Capsicums. In Chemistry and Human Health, $2^{\text {nd }}$ Edition. (Eds. Elhadi M. Yahia. John Wiley \& Sons, Ltd. 2017), Chap 45. pp. 957-968. https://doi.org/10.1002/9781119158042.ch45

Bridgemohan, P., Mohammed, M., Bridgemohan, R. S. H., \& Mohammed, Z. (2018a). Hot peppers: VII. Efficacy of chemical preservatives on quality and stability in red hot peppers (Capsicum chinensis L.). Clin J Nutr Diet, 1(2), 1-12.

Bridgemohan, P., Mohammed, M., Bridgemohan, R. S. H., \& Mohammed, Z. (2018b). Hot Peppers: XII. Towards a Quality Assurance Model for Caribbean hot pepper (Capsicum chinensis L.) fresh fruits and processed products. $24^{\text {th }}$ International Pepper Conference, Fort Myers, FL. Nov 4-6 ${ }^{\text {th }}, 2018$

Bridgemohan. P., Mohamed, M., Mohammed, M., \& Bridgemohan, R. S. H. (2017a). Hot Peppers: VI. Effect of a biostimulant, selected agronomic practices and fruit characteristics on the relative pungency in Caribbean hot peppers. Academia Journal of Agricultural Research, 5(10), 255-260.

Draughon, F. A., Elahi, I. E., \& Mc Carty, I. E. (1981). Microbial Spoilage of Mexican-Style Sauces. Journal of Food Protection, 44, 284-287. https://doi.org/10.4315/0362-028X-44.4.284

Esa, S. A. R. M., Thangaraj, S., \& Shajahan, E. N. (2010). Antimicrobial and biochemical analysis of some spices extract against food spoilage pathogens. Int. Journal of Food Safety, 12, 71-75.

Flagan, S. F., \& Leadbetter, J. R. (2006). Utilization of capsaicin and vanillylamine as growth substrates by Capsicum (hot pepper) associated bacteria. Environmental Microbiology, 8(3), 560-565. https://doi.org/10.1111/j.1462-2920.2005.00938.x

Flores, N. C., VanLeeuwen, D., \& Pennock, R. D (2007). The effect of calcium on microbial quality and consistency of chile pepper (Capsicum annuum cv. Mesilla Cayenne) mash during fermentation. Food Science and Technology, 40(8), 1482-1487.

Getenit, H., Seyoum, T., \& Woldetsdik, K. (2008). The effect of cultivar, maturity stage and storage environment on quality of tomatoes. J Food Eng., 87, 467-498. https://doi.org/10.1016/j.jfoodeng.2007.12.031

Gibbs, H. A. A., \& O'Garro, L. W. (2004). Capsaicin content of West Indies hot pepper cultivars using colorimetric and chromatographic techniques. HortScience., 39, 132-135. https://doi.org/10.21273/HORTSCI.39.1.132

Gogus, F., \& Sami, E. R. E. N. (1998). Effect of temperature and pH on nonenzymatic browning in minced dried pepper during storage. Turkish Journal of Engineering and Environmental Sciences, 22(1), 33-38 
Gogus, F., Ozel, M. Z., Keskin, H., Yanık, D. K., \& Lewis, A. C. (2015). Volatiles of Fresh and Commercial Sweet Red Pepper Pastes: Processing Methods and Microwave Assisted Extraction. International Journal of Food Properties, 18(8), 1625-1634. http://dx.doi.org/10.1080/10942912.2014.923910

Gomez, F. R., Canessa, M. W., Fuentes, R. G., \& Mora, W. (1988). Preliminary survey of chili cultivars (Capsicum spp.) Capsicum Newsletter, 7, 47-48.

Han, Y., Linton, R. H., Nielsen, S. S., \& Nelson, P. E. (2000). Inactivation of Escherichia coli O157: H7 on surface-uninjured and-injured green pepper (Capsicum аппиит L.) by chlorine dioxide gas as demonstrated by confocal laser scanning microscopy. Food Microbiology, 17(6), 643-655. https://doi.org/10.1006/fmic.2000.0357

Kim, S. A., Koo, H. J., Kim, K. S., \& Park, J. B. (2006). Characteristics of Korean single-harvested pepper (Capsicum annuum, L.) flakes and the effects on the quality of various dressings. Korean Journal of Food and Cookery Science, 22(1), 12-21.

Koh, F. M. (2005). Physicochemical properties of pepper mash fermented in wood and plastic $J$ Food Sci Technol., 50(5), 842-855.

Kuleaşan, H., \& Okur, M. (2012). Industrial production of traditional red pepper paste and prevention of spoilage during storage. Journal of Food Agriculture \& Environment, 10(2), 241-246.

Lee, D. S., Jang, J. D., \& Hwang, Y. I. (2002). The effects of using packaging films with different permeability on the quality of Korean fermented red pepper paste. International Journal of Food science \& Technology, 37(3), 255-261. https://doi.org/10.1046/j.1365-2621.2002.00564.x

Medlicott, A. P., \& Thompson, A. K. (1985). Analysis of sugars and organic acids in ripening fruits by high performance liquid chromatography. J Sci Food Agric., 36, 561-566. https://doi.org/10.1002/jsfa.2740360707

Mignani, I, Greene, L. C., Ben-arie, R., Stotz, H. U., Li, C., Shakel, K., \& Labavitrich, J. (1995). The effect of GA and divalent cations on aspects of pectin metabolism and tissue softening in ripening tomato pericarp. Physiol. Plant, 93, 108-115. https://doi.org/10.1034/j.1399-3054.1995.930116.x

Mizrach, A., Filtsanov, U., \& Fuchs, V. (1997). An ultrasonic nondestructive method for measuring maturity of fruit. Trans ASAE., 40, 1107-1111. https://doi.org/10.13031/2013.21327

Mohamed, M., \& Bridgemohan, P. (2014 a). Hot peppers V. Breeding multi-purpose hot peppers for increased capsaicinoids content. Acta Hort., 1047, 63-68. https://doi.org/10.17660/ActaHortic.2014.1047.5

Mohamed, M., \& Bridgemohan, P. (2014b). Hot peppers IV. Rapid qualitative assessment methodology to determine postharvest levels of capsaicinoid content in ornamental hot pepper crosses. Acta Hort., 1047, 69-73. https://doi.org/10.17660/ActaHortic.2014.1047.6

Mohammed, M., \& Wickham, L. D. (1999). Effect of modified atmosphere packaging and ethanol on the deastringency process in jamun (Syzygium cuminii) fruit. Journal of Applied Horticulture, 2(1), 105-107.

Mohammed, M., Wilson, L. A., \& Gomes, P. I. (1999). Postharvest sensory and physiochemical attributes of processing and non-processing tomato cultivar. J Food Qual., 22, 167-182.

https://doi.org/10.1111/j.1745-4557.1999.tb00549.x

Mohammed, M., Wilson, L. A., \& Gomes, P. I. (2014). Occurrence, manifestation and alleviation of chilling injury of hot peppers (Capsicum chinense L.). Acta Horticulturae, 1016, 89-94. https://doi.org/10.17660/ActaHortic.2014.1016.10

Mohammed, M., Wilson, L. A., \& Gomes, P. I. (2016). Sodium hypochlorite combined with calcium chloride and modified atmosphere packaging reduces postharvest losses of hot pepper. International Journal of Research and Scientific Innovation, 3(10), 1-9. Retrieved from https://www.rsisinternational.org

Pothakos, E., \& Vasileios, E. (2010). Spoilage potential of psychrotrophic lactic acid bacteria (LAB) species: Leuconostoc gelidum subsp. gasicomitatum and Lactococcus piscium, on sweet bell pepper (SBP) simulation medium under different gas compositions. International Journal of Food Microbiology, 178, 120-129. https://doi.org/10.1016/j.ijfoodmicro.2014.03.012

Rico, C., Kim, W., Ahn, G. R., Kim, J. J., Furuta, H. K., \& Kwon, J. H. (2010). The comparative effect of steaming and irradiation on the physicochemical and microbiological properties of dried red pepper 
(Capsicum annum L.). Food Chemistry, 119(3), 1012-1016. https://doi.org/10.1016/j.foodchem.2009.08.005.

Samira, A., Woldetsadik, K., \& Workneh, T. S. (2013). Postharvest quality and shelf life of some hot pepper varieties. Journal of Food Science and Technology, 50(5), 842-855. https://doi.org/10.1007/s13197-011-0405-1.

Stanley, D. W., Bourne, M. C., Stone, A. P., \& Wismer, W. V. (1995). Low temperature blanching effects on chemistry, firmness and structure of canned beans and carrots. Food Sci., 60, 327-333. https://doi.org/10.1111/j.1365-2621.1995.tb05666.x

Vega-Gálvez, A., Di Scala, K., Rodríguez, K., Lemus-Mondaca, R., Miranda, M., López, J., \& Perez-Won, M. (2009). Effect of air-drying temperature on physico-chemical properties, antioxidant capacity, colour and total phenolic content of red pepper (Capsicum annuum, L. var. Hungarian). Food Chemistry, 117(4), 647-653. https://doi.org/10.1016/j.foodchem.2009.04.066.

Yildiz, G. (2018). The effect of different chemical agents on the preservation of enzymatic browning in banana. Journal of Food Science and Engineering, 7, 91-96.

Yu, S., Yu-Yun, C., \& Ni-Lun, T. (2005). Capsaicin biosynthesis in water-stressed hot pepper fruits. Bot. Bull. Acad. Sin., 46, 35-42. https://ejournal.sinica.edu.tw/bbas/content/2005/1/Bot461-05.html

\section{Appendix}

Table 1. Effects of preserving agents and capping on colour stability

\begin{tabular}{|c|c|c|c|c|c|c|c|c|}
\hline \multirow[b]{2}{*}{ Sealant cap } & \multirow[b]{2}{*}{ Preserving agent } & \multicolumn{4}{|c|}{ Red colour peppers } & \multicolumn{3}{|c|}{ Yellow colour peppers } \\
\hline & & $\mathrm{L}^{*}$ & $a^{*}$ & $\mathrm{~b}^{*}$ & hue & $\mathrm{L}^{*}$ & $a^{*}$ & $\mathrm{~b}^{*}$ \\
\hline \multirow[t]{5}{*}{ Oil } & 1 Citric Acid & 36.16 & 7.69 & 13.48 & 60.29 & 35.23 & 6.00 & 13.44 \\
\hline & 2Control & 36.24 & 6.59 & 13.29 & 63.62 & 36.24 & 6.59 & 13.29 \\
\hline & 3Alcohol & 33.46 & 10.03 & 6.10 & 31.30 & 35.59 & 5.76 & 13.3313 .4 \\
\hline & 4Acetic Acid & 31.83 & 11.79 & 6.54 & 29.01 & 36.16 & 7.69 & 13.48 \\
\hline & 5Sodium Benzoate & 31.35 & 9.08 & 6.21 & 34.36 & 32.75 & 5.81 & 10.57 \\
\hline \multirow[t]{5}{*}{ Salt } & Citric Acid & 31.50 & 10.36 & 6.49 & 32.06 & 36.02 & 3.19 & 4.26 \\
\hline & Control & 32.67 & 6.31 & 6.35 & 45.18 & 32.24 & 5.69 & 8.66 \\
\hline & Alcohol & 31.09 & 8.44 & 5.82 & 34.58 & 33.29 & 4.45 & 6.41 \\
\hline & Acetic Acid & 33.43 & 5.63 & 6.16 & 47.57 & 35.39 & 6.46 & 11.84 \\
\hline & Sodium Benzoate & 30.96 & 7.12 & 5.84 & 39.35 & 32.24 & 5.31 & 6.70 \\
\hline \multirow[t]{6}{*}{ zero } & Citric Acid & 32.01 & 16.92 & 9.63 & 29.64 & 26.57 & 2.73 & 0.49 \\
\hline & Control & 31.37 & 11.40 & 6.37 & 29.19 & 37.86 & 6.53 & 14.93 \\
\hline & Alcohol & 32.65 & 9.58 & 6.34 & 33.49 & 33.63 & 6.26 & 7.59 \\
\hline & Acetic Acid & 35.95 & 5.76 & 13.33 & 66.63 & 34.84 & 7.46 & 14.83 \\
\hline & Sodium Benzoate & 28.95 & 8.85 & 5.15 & 30.19 & 33.02 & 6.46 & 11.44 \\
\hline & $\mathrm{X}[\mathrm{SE}]$ & $33.2[0.479]$ & $7.8[0.594]$ & $8.7[0.743]$ & 29.01 & 34.07 [0.689] & $5.75[0.358]$ & 9.86 [1.15] \\
\hline
\end{tabular}


Table 2. Effect of the cap $\mathrm{x}$ treatment on microbial infection (\%)

\begin{tabular}{|c|c|c|c|c|c|c|c|}
\hline \multirow[t]{3}{*}{ Colour } & \multirow[t]{3}{*}{ Treatment } & \multicolumn{6}{|l|}{ Caps } \\
\hline & & \multicolumn{2}{|l|}{ Salt } & \multicolumn{2}{|l|}{ Oil } & \multicolumn{2}{|l|}{ No cap } \\
\hline & & $\begin{array}{l}\text { microbial } \\
\text { infection }\end{array}$ & Discoloration & $\begin{array}{l}\text { microbial } \\
\text { infection }\end{array}$ & Discoloration & $\begin{array}{l}\text { microbial } \\
\text { infection }\end{array}$ & Discoloration \\
\hline \multirow[t]{5}{*}{ Yellow } & Citric acid & 9 & 42 & 6 & 10 & 23 & 11 \\
\hline & Alcohol & 50 & 46 & 0 & 47 & 82 & 75 \\
\hline & Acetic acid & 34 & 51 & 0 & 33 & 100 & 39 \\
\hline & $\begin{array}{l}\text { Sodium } \\
\text { benzoate }\end{array}$ & 0 & 63 & 5 & 10 & 23 & 40 \\
\hline & Control & 71 & 71 & 0 & 10 & 8 & 15 \\
\hline \multirow[t]{6}{*}{ Red } & Citric acid & 0 & 10 & 0 & 33 & 35 & 6 \\
\hline & Alcohol & 68 & 15 & 12 & 24 & 30 & 43 \\
\hline & Acetic acid & 44 & 39 & 10 & 54 & 44 & 24 \\
\hline & $\begin{array}{l}\text { Sodium } \\
\text { benzoate }\end{array}$ & 8 & 55 & 0 & 38 & 61 & 22 \\
\hline & Control & 85 & 35 & 0 & 0 & 19 & 15 \\
\hline & & $36.9[10.01]$ & $42.70[6.10]$ & $3.3[1.48]$ & $25.90[5.69]$ & $42.5[9.38]$ & $29.0[6.54]$ \\
\hline
\end{tabular}

\section{Copyrights}

Copyright for this article is retained by the author(s), with first publication rights granted to the journal.

This is an open-access article distributed under the terms and conditions of the Creative Commons Attribution license (http://creativecommons.org/licenses/by/4.0/). 